\title{
Comment
}

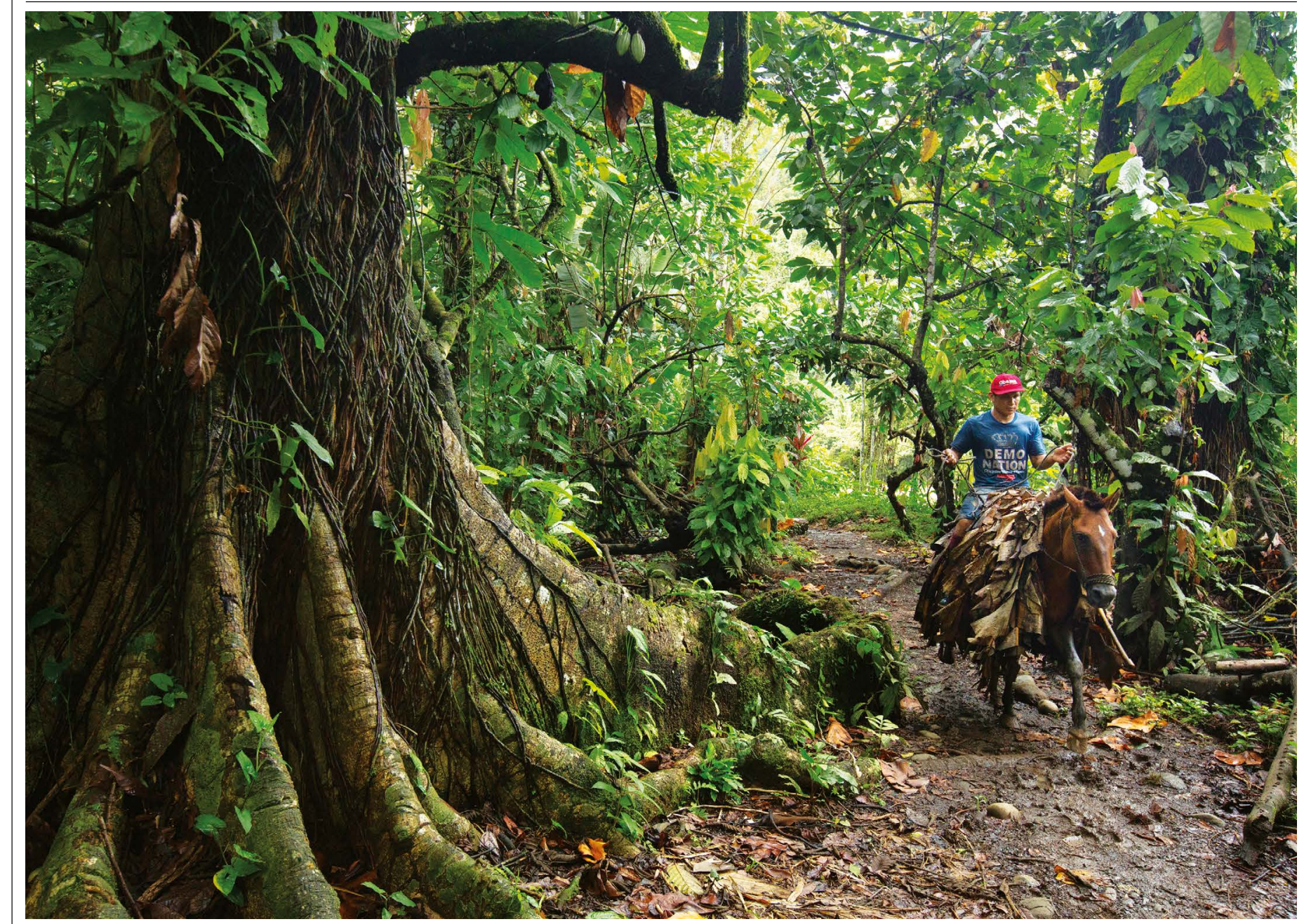

A tropical forest in the Bribri Indigenous region of Costa Rica.

\section{Adopt a carbon tax to protect tropical forests}

Edward B. Barbier, Ricardo Lozano, Carlos Manuel Rodríguez \& Sebastian Troëng

A levy on fossil fuels can support and restore ecosystems that help to stem climate change.

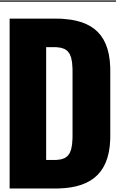

eforestation must be stopped in tropical countries to tackle the existential threats of climate change and biodiversity loss. The vast majority of Earth's species are in the tropics; forests there have taken in much of the carbon added to the atmosphere by human activities. Safeguarding these forests is central to slashing greenhouse-gas emissions and meeting the internationally agreed United Nations Sustainable Development Goals (SDGs) ${ }^{1}$.
Sadly, in tropical countries and internationally, investments are woefully inadequate in conservation, restoration and improving land management to protect biodiversity and ecosystem services collectively called 'natural climate solutions ${ }^{\prime 1,2}$.

To plug this gap, we urge more countries that have tropical forests to adopt a tropical carbon tax - in South and Central America, Africa, Asia and the Pacific. This is a levy on fossil fuels that is invested in natural climate 


\section{Comment}

solutions. Such a policy can reduce the use of oil, gas and coal and mobilize domestic funds for adaptation and mitigation.

Costa Rica and Colombia have done this. Our own analysis shows that, if 12 other countries roll out a tropical carbon tax similar to Colombia's, they could raise US $\$ 1.8$ billion each year between them to invest in natural habitats that benefit the climate (see Supplementary Information).

We call on governments, development banks, financial investors and non-governmental organizations to support those countries that need financial and technical help to implement this policy, and to ensure that the money raised is spent efficiently and effectively.

\section{Twin threats}

Almost one-quarter of the emissions caused by humans come from agriculture, forestry, fibre and livestock production ${ }^{3}$. It has been estimated that tropical deforestation can contribute as much to emissions as do some large nations (see go.nature.com/37gmwvy). If present trends continue, by 2050 the world will have lost a further area of tropical forest almost the size of India -289 million hectares ${ }^{4}$. This could squander half of the remaining global carbon budget for limiting warming to $1.5^{\circ} \mathrm{C}$ above pre-industrial levels ${ }^{4}$.

Meanwhile, more than three-quarters of species live in the tropics. These are under greater threat of extinction than is life elsewhere, mainly because of deforestation ${ }^{5}$.

There is a quick, cheap way to halt these trends: reducing the conversion of land in the tropics, especially of forests, peatlands and mangroves. Alongside cuts to fossil-fuel emissions, up to $37 \%$ of the mitigation needed to hold warming to the Paris agreement goal (to avoid the catastrophic impacts of climate change) might be achieved in this way, at a cost of less than $\$ 100$ per tonne of $\mathrm{CO}_{2}$ equivalent ${ }^{1}$ - the standard measure for greenhouse-gas emissions. One-third of these mitigation options could cost less than $\$ 10$ per tonne ${ }^{1}$.

But ecosystem conservation, restoration and management received just $3 \%$ of global finance for climate mitigation in 2017-18: an average of $\$ 18$ billion $^{6}$. Most of the remainder was spent on renewable-energy generation and on investments in low-carbon transport, such as railways and electric vehicles ${ }^{6}$.

Extra cash is unlikely to come from the international community in the near future, and aid and other funding is already scarce for biodiversity conservation in tropical countries ${ }^{2}$. Such nations urgently need a new way to fund natural solutions to climate change.

\section{Case studies}

Colombia and Costa Rica have blazed a trail. Since 1997, Costa Rica has collected a $3.5 \%$ tax on fossil fuels. That now generates $\$ 26.5 \mathrm{mil}$ lion per year $^{7}$ (see go.nature.com/3jdpmtk; in Spanish). The tax was negotiated in Costa Rica's legislative assembly and supported by research from the non-governmental Tropical Science Center in San José, which examined the benefits of forests to the country's economy. Implementation faced little opposition because the tax was incorporated with other fiscal reforms. Surveys of fossil-fuel users indicated that they did not object if revenues were directed to forest conservation.

To invest the money raised, Costa Rica created its National Forest Fund (FONAFIFO). For example, from 1997 to 2018, the fund paid

\section{"Investments in protecting biodiversity to reduce carbon emissions can favour poor people."}

out to landowners across $23.5 \%$ of the country - an area of 1.2 million hectares. They spent the money on projects to protect 1 million hectares of mature forest and 71,000 hectares under reforestation. The fund supports conservation of mature forests, reforestation using native or exotic species, and agroforestry systems that use a mix of trees and crops or grasslands. It has disbursed $\$ 500$ million to roughly 18,000 people, including those living across 162,000 hectares of Indigenous lands, such as the Cabécar and Bribri territories. Transparency and accountability of the fund's operations are important to its success and continued popularity, so strategic and operational plans, budgets, financial statements and other details are available online (see www.fonafifo.go.cr).

In the 1980s, Costa Rica had the highest deforestation rates in the world. Forest cover more than doubled between 1986 and 2013, rising to $53 \%$ (ref. 8). Although estimates remain uncertain, we think that the fossil-fuel tax, along with a decline in the profitability of livestock and the expansion of protected areas and ecotourism, contributed to this. The programme funded by the fuel tax has been especially effective away from protected areas and their buffer zones?.

Colombia rolled out a carbon tax in 2016 as part of sweeping fiscal reforms. These garnered broad political support because of the need to raise money for the country's peace process. The carbon tax was developed by the Ministry of Finance and Ministry of Environment and Sustainable Development, and is collected from companies producing or importing fossil fuels.

Colombia's tax of $\$ 5$ per tonne of emitted carbon yielded revenues of $\$ 148$ million in 2017 and \$91 million in 2018 (see go.nature.com/3b8ufkj; in Spanish). These go to the Colombian Peace Fund (Fondo Colombia en Paz), from which $25 \%$ is used to manage coastal erosion, reduce and monitor deforestation, conserve water

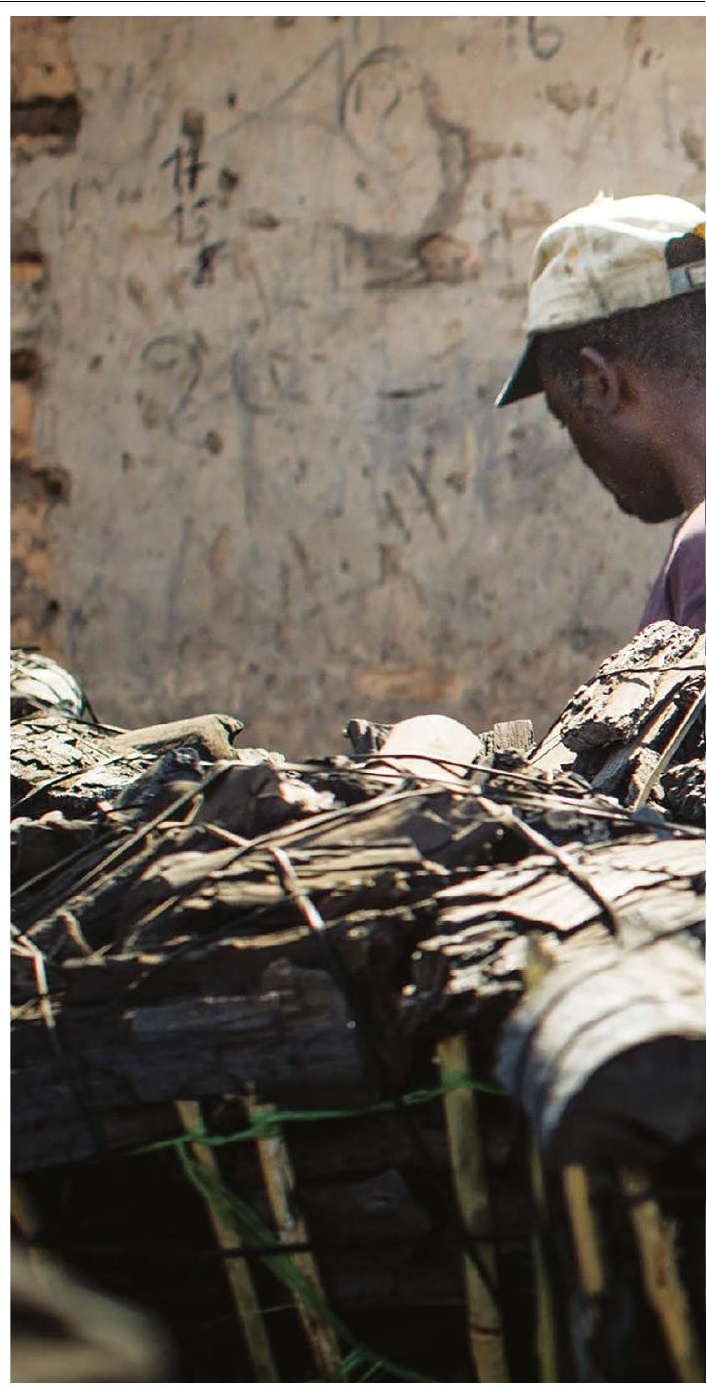

sources, protect strategic ecosystems and combat climate change. A further 5\% is used to strengthen Colombia's National System of Protected Areas. The revenue will be used for conservation projects in the following prioritized areas: flood-plain forests, tropical montane cloud forests, tropical humid forests, tropical savannahs and Andean forests. These projects are in the development phase and are waiting to access the fund. There is also a project to enhance the Colombian Environmental Information System (SIAC), a web-based platform that provides official information on the state of the country's natural resources and which is under development (see go.nature. com/2hthzqw; in Spanish).

A mechanism called carbon neutrality allows companies to reduce their tax burdens by buying certified carbon credits from conservation and restoration projects in Colombia that adhere to internationally recognized standards. For example, a company might buy a credit in a region that promotes social initiatives with communities that are involved in managing these projects. This is the case for communities in the Chocó departmental 


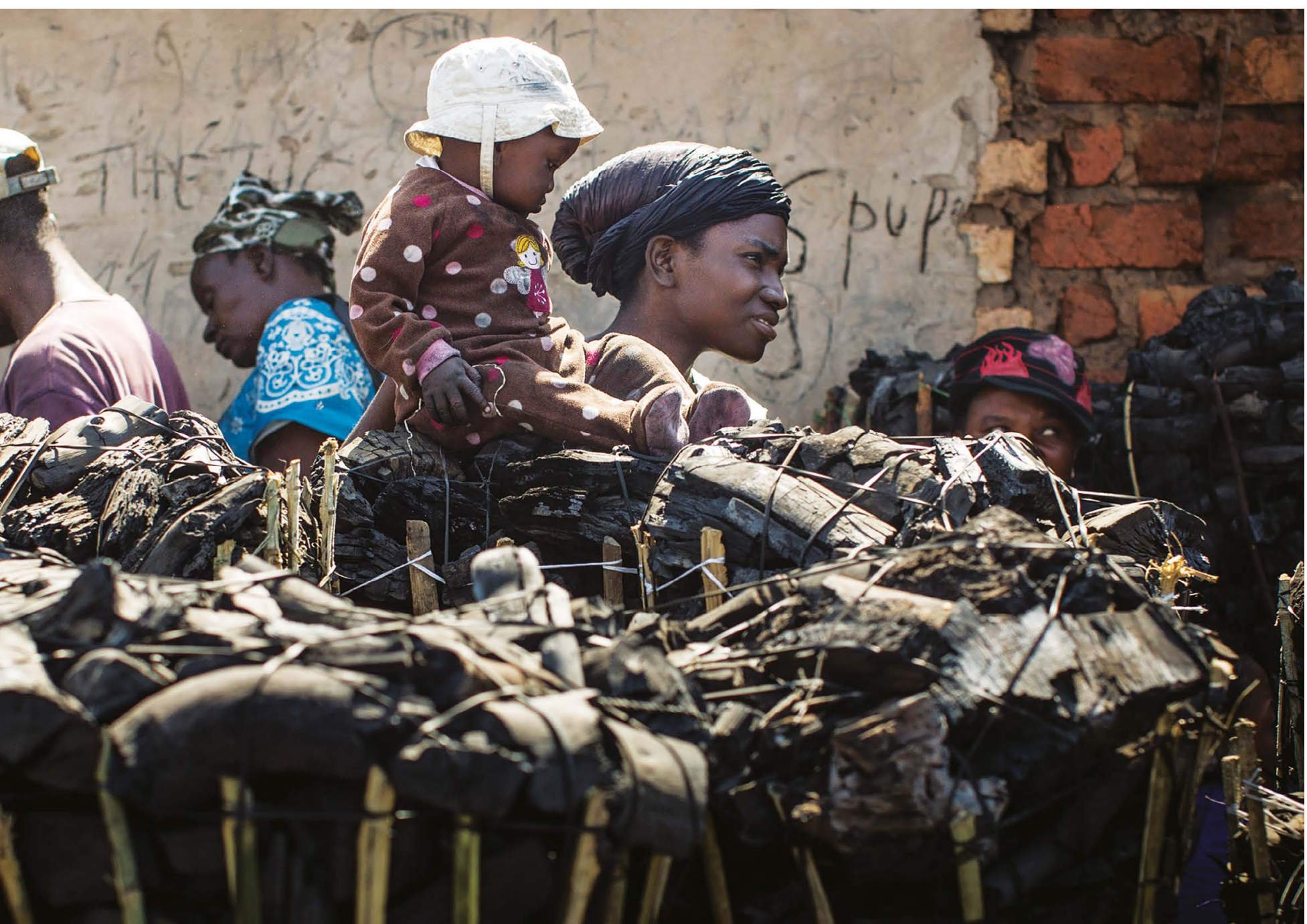

People in the Democratic Republic of the Congo at a charcoal market - the fuel is one of the causes of deforestation in the country.

region of northwestern Colombia, such as those living near towns including Acandí, El Carmen del Darién and Baudó.

\section{Join in}

Up to $70 \%$ of the world's biodiversity is found in just 17 'megadiverse' countries ${ }^{10}$. Thirteen contain tropical forests. In 2018, these countries lost almost 7.3 million hectares of forests - an area roughly the size of Panama. According to our estimates, that represented nearly $30 \%$ of global deforestation and may have released about $7 \%$ of worldwide carbon emissions (see Supplementary Information and www.globalforestwatch.org/map).

Two scenarios illustrate how these countries could benefit from a tropical carbon tax ${ }^{11}$ (see also Supplementary Information). The first assumes that each follows a similar policy to that of Colombia, introducing a tax of $\$ 5$ per tonne of carbon emitted, and allocating 30\% of the revenues to natural solutions to climate change and measures that conserve forests. The second assumes a tax of $\$ 15$ per tonne of carbon emitted and $70 \%$ allocation.

We provide this second option because we think that both the urgency and interest in addressing climate change and biodiversity loss will continue to grow. It is also likely that some governments will choose to adopt such a higher carbon price and allocate more revenues to natural climate solutions.

For some countries, notably India, the Philippines, Mexico, Ecuador and Malaysia, the sums raised could provide hundreds of dollars per hectare to counter forest loss. The more ambitious policy could yield nearly $\$ 13$ billion each year for natural climate solutions.

Brazil, the Democratic Republic of the Congo and Indonesia would benefit the most, because they currently have the greatest amount of deforestation. Countries that have experience in developing high-quality carbon-offset projects, such as Peru and Ecuador, are well positioned to adopt a tropical carbon tax (see go.nature.com/2tptk21).

\section{Politically challenging}

There are three main criticisms of funding natural climate solutions through carbon taxes. First, that they cause 'leakage' - the displacement of deforestation to other areas.
Second, that they reduce the incentive to reduce emissions through renewable energy. And third, that the tax revenue should be used for other purposes.

We think that each of these problems can be addressed. National tax schemes reduce the likelihood of leakage in each country. Renewable-energy production and natural climate solutions are both essential, as indicated by scenarios from the Intergovernmental Panel on Climate Change ${ }^{3}$. Finally, although there are many worthy uses of tax revenue, the severity of climate change and biodiversity loss means that stemming both at once is a development priority for tropical-forest countries.

We also recognize that it can be politically challenging to introduce measures that increase the cost of living. But as the examples in Costa Rica and Colombia illustrate, investments in protecting biodiversity to reduce carbon emissions can favour poor people because such investments have wider social benefits beyond landowners and parks ${ }^{9}$. In Costa Rica, forests and high levels of poverty can often be found in the same districts, so 


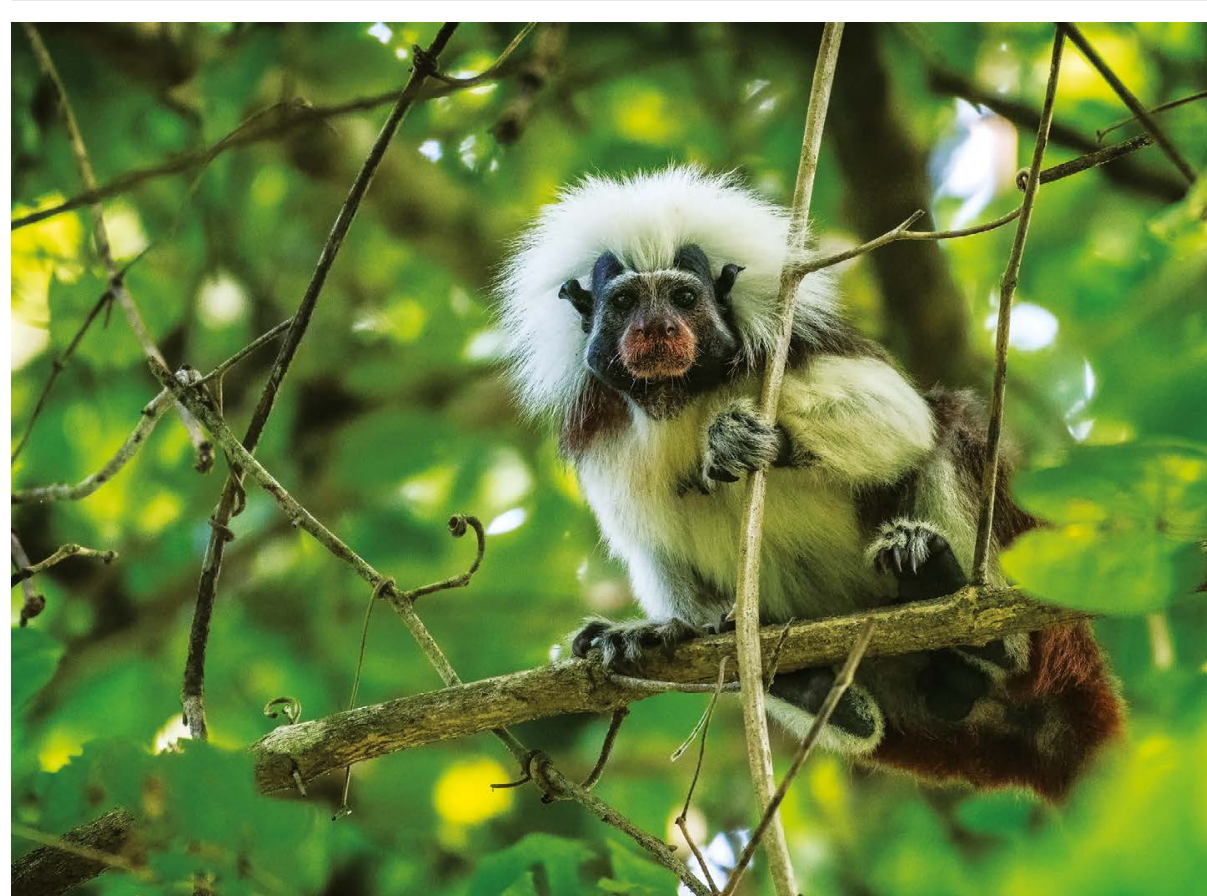

A cotton-top tamarin (Saguinus oedipus) in one of Colombia's protected national parks.

revenues destined for conservation can also contribute to social development. The Costa Rican government prioritizes such districts for payouts for ecosystem services. It also assists smallholder farmers and Indigenous communities in submitting requests for funds. Today, $40 \%$ of beneficiaries in Costa Rica are communities that live below the poverty line.

Ecosystem services such as drinking-water supply, food provision and cultural services are estimated to contribute between 50\% and $90 \%$ of income and subsistence among the rural poor and those who live in forests ${ }^{12}$. Such services can make an important contribution to ending extreme poverty (SDG 1), achieving zero hunger (SDG 2), improving health (SDG 3) and meeting many of the other $14 \mathrm{SDGs}^{12}$.

\section{International support}

The World Bank, the International Monetary Fund (IMF) and other multilateral agencies should encourage more countries to adopt a tropical carbon tax. The IMF already promotes carbon taxes as an efficient and fiscally responsible way of reducing emissions, with revenues being used for much-needed public investments in developing countries ${ }^{13}$. The international community can support more-widespread adoption of a tropical carbon tax in two important ways.

First, some tropical-forest countries and other low-income nations will require extra financial assistance because they might be unable to raise sufficient funds from a carbon tax. For example, if Papua New Guinea, Madagascar and the Democratic Republic of the Congo adopted Colombia's approach for combating each hectare of forest loss with natural climate solutions, they would generate only $\$ 23, \$ 3$ and $\$ 1$ per hectare, respectively (see Supplementary Information). Top-up financing could come from bilateral assistance, or from the Special Climate Change Fund and the Least Developed Countries Fund. Both of these

\section{"The severity of climate change and biodiversity loss means that stemming both at once is a priority."}

are managed by the Global Environmental Facility for the UN Framework Convention on Climate Change (UNFCCC).

Second, many tropical-forest countries will require technical support to guide and monitor their investments. Countries should comply with recognized global quality marks such as the Verified Carbon Standard (https:// verra.org/project/vcs-program) and the Climate, Community and Biodiversity Standard(https://verra.org/project/ccb-program). The first is the world's most widely used voluntary programme for mitigating greenhouse-gas emissions. The second identifies projects that simultaneously address climate change, support local communities and smallholders, and conserve biodiversity. Currently, the projects that have been validated and verified encompass more than 10 million hectares, an area the size of Iceland (see https://verra.org/project/ccb-program).

Tropical countries are already showing interest in carbon-pricing initiatives and natural climate solutions. Next week, Costa Rica will host a high-level meeting on the subject in San José with government and business leaders from Peru, Ecuador, Mexico and Chile, as well as Colombia.

And several major international events in 2020 provide a platform for supporting global action towards a tropical carbon tax. These include the International Union for Conservation of Nature's World Conservation Congress in June, the 15th meeting of the Conference of the Parties (COP15) to the Convention on Biological Diversity in Kunming, China, in October, and the 26th session of the UNFCCC Conference of the Parties (COP26) in Glasgow, UK, in November. We suggest that, at these meetings, policymakers explicitly highlight and incorporate a tropical carbon tax in agreements and decisions.

Tropical deforestation and land-use change must be halted to safeguard the climate and global biodiversity. The widespread adoption of a tropical carbon tax is a practical way forward.

\section{The authors}

Edward B. Barbier is a university distinguished professor in the Department of Economics, Colorado State University, Fort Collins,

Colorado, USA. Ricardo Lozano is Minister of Environment and Sustainable Development, Colombia. Carlos Manuel Rodríguez is Minister of Environment and Energy, Costa Rica. Sebastian Troëng is executive vice-president of Conservation International in Arlington, Virginia, USA.

e-mail: edward.barbier@colostate.edu

1. Griscom, B. W. et al. Proc. Natl Acad. Sci. USA 114 11645-11650 (2017).

2. Barbier, E. B., Burgess, J. C. \& Dean, T. J. Science $\mathbf{3 6 0}$, 486-488 (2018).

3. Intergovernmental Panel on Climate Change. Special Report on Climate Change and Land (eds Shukla, P. R. et al.) (IPCC, 2019).

4. Busch, J. \& Engelmann, J. Environ. Res. Lett. 13, 015001 (2017).

5. Barlow, J. et al. Nature 559, 517-526 (2018).

6. Climate Policy Initiative. Global Landscape of Climate Finance 2019 (CPI, 2019)

7. National Fund for Forest Finance (FONAFIFO). 2019 Budget Plan [In Spanish] (FONAFIFO, 2018).

8. Costa Rican Ministry of Environment and Energy. Report on the State of the Environment 2017 [In Spanish] (2018); available at https://go.nature.com/3b9ynev

9. Robalino, J., Sandoval, C., Barton, D. N., Chacon, A. \& Pfaff, A. PLoS ONE 10, e0124910 (2015).

10. Mittermeier, R. A., Robles-Gil, P. \& Mittermeier, C. G. (eds) Megadiversity. Earth's Biologically Wealthiest Nations (CEMEX/Agrupación Sierra Madre, 1997).

11. Boden, T. A., Marland, G. \& Andres, R. J. Global, Regional, and National Fossil-Fuel $\mathrm{CO}_{2}$ Emissions (1751-2014) (v. 2017) https://doi.org/10.3334/CDIAC/00001_V2017 (US Department of Energy, 2017).

12. Convention on Biological Diversity. Biodiversity and the 2030 Agenda for Sustainable Development: Technical Note (CBD, 2019).

13. International Monetary Fund. Fiscal Monitor: How to Mitigate Climate Change (IMF, 2019).

Supplementary Information accompanies this article: see go.nature.com/31wakvj. 